ments. Even after the publication, many groups throughout the world doubted whether it was a cortical event; Grey's attitude was firm, 'Let them spend time doubting, it will take them longer to catch us up.' $\mathrm{He}$ was unconcerned about money and in the 1950 s was content with such a low salary that the income tax inspector did not believe his declared income. Yet over the years Grey obtained hundreds of thousands of pounds for the equipment and work at the Burden Institute. I think that he considered that to be able to work on brain research was a privilege that had to be paid for and I am sure that he would have continued working for nothing if the necessity had arisen. Work was a major passion in his life and he would spend many, many hours in the laboratory trying out new ideas often without any real lead to follow, persisting in the belief that discoveries are made in the laboratory and not at the desk or committee meetings. It is a pity that there are so few like him.

R. Cooper

\section{Frank Green}

Dr Frank Green, CBE, MD, who died on 30 April 1977 in his 77 th year, had lived his professional life as a research administrator. From 1929 to 1955 he served the Medical Research Council rising through the various grades from Medical Officer to Principal and at the end of his period was Publications Editor. Their special reports were perhaps appropriately named "Green" books.

He worked under a succession of Secretaries from Sir Walter Fletcher and Sir Edward Mellanby to Sir Harold Himsworth. In the pre-war period of his MRC service the annual budget, allocated directly by the Privy Council, rose from approximately $£ 150,000$ to nearly $£ 200,000$. The organisation remained small, intimate and friendly and its relationships with a small band of research workers were personal, smooth running and inexpensive. Frank got to know them all and his wife Joyce acted as a charming hostess to many of us.

The MRC then occupied a pleasant old Georgian house at 38 Old Queen Street and the Council acted with an ease of judgement and the lightest of control. Research was still cheap, equipment often home made at laboratory benches, and grantees were trusted to spend their modest (often threefigure) allocations to the advantage of their experiments, which were, in those days, usually pursued with their own hands, with very limited technical help. When the War ended in 1945 the Treasury began to intervene in the allocations which in 1946 reached half a million pounds, and were subsequently multiplied to two million by 1955. The MRC was now growing into a larger and less informal body, personal contacts became less easy to maintain, and the channels of communication became more complex.

Frank then side-stepped into the growing Wellcome Trust thus coming back into a much smaller organisation, in which he was in continuous daily contact with the chairman, Sir Henry Dale, the doyen of medical science of our era. The Wellcome funds at that time were limited to a few hundred thousand pounds and decisions of great responsibility fell largely to Dale's admirable scientific judgement combined with Green's personal knowledge of research applicants.

The allocations in those days were mainly to provide for costly equipment such as electron microscopes and many new laboratories of which the Medical Schools were in dire need. Indeed with out help from the Wellcome Trust medical research in our Universities in the immediate post-war years would have been severely hampered. Frank as the Executive Secretary was thus a trusted and key figure approached by everybody in need of supplements. Extrapolating backwards through his experience of the MRC he had indeed been a key figure in facilitating almost the whole development of British medical research from 1930 into the present era. His experience as Editor in the MRC gave him a capacity to work hard on drafts and produce his reports in impeccable English.

$\mathrm{He}$ was frequently invalided, often crippled by bronchitis and asthma. $\mathrm{He}$ worked to the limit of his capacity until recurrent illnesses each winter made it difficult for him to continue with his growing responsibilities while other physical disabilities also made him less mobile. When he relinquished his advisory services to the Wellcome Trust he gave part time services to the Science Committee of the growing British Heart Foundation. Once again his knowledge of personalities and his experience in judging applications helped to create a system in which the expertise of the various committees was always supplemented by consultation with appropriate experts in collateral fields. He thus epitomised in himself the ethics of research development and support based on the highest judgement of achievement and an intimate knowledge not only of the applicants and their sponsors but also of suitable referees.

$\mathrm{He}$ endured a long physical illness with patience supported and nursed by his loyal and devoted wife who always welcomed visits from their old friends.

Sir John McMichael

\section{F. Lucas Keene}

Professor Mary Frances Lucas KEENE, doyenne of British anatomists, was born 15 August 1885 and died 9 May 1977. Her professional life was dedicated to the Royal Free Hospital School of Medicine (formerly London School of Medicine for Women), to the interests of the medical profession and the enhancement of the status of women therein. A brilliant undergraduate in the School she attracted encouragement from Stanley Boyd and F. G. Parsons and after adopting a career in anatomy was later influenced by F. Wood Jones. She graduated MB, BS in 1911 and joined the School's anatomy department to serve it with distinction as Lecturer in Embryology and Senior Demonstrator of Anatomy (1914), Lecturer and Head of Department (1919) and University Professor (1924-51). On retirement she was elected Emeritus Professor in the University of London.

Her principal researches were neurological and produced meticulous studies of the posterior commissure, the subcommissural region, muscle spindles and intramuscular sensory organs: her pioneer investigations of the process of myelination earned the award of the DSc of London University.

Lucas Keene was exceptionally endowed with powers of organisation and judicial assessment and was wholeheartedly committed to duty. These qualities gained early recognition and were inevitably empanelled in the general service of School and University. Without remission of departmental commitment she accordingly assumed and discharged with notable success an onerous burden of scholastic and administrative business which involved, during the Second World War, added responsibility for the School's migrant preclinical departments and the reconstruction of its bomb-devastated premises.

Her integrity and profound common sense fortified by her personal dignity and charm, redounded to her School's prestige and engendered wide extramural appreciation of her judgement and counsel. Her achievements and services were fittingly recognised by her election to the presidency of the School of Medicine (1956-74), of the Anatomical Society (1949-51) and of the Medical Women's Federation (1946-49), to vice-presidency of the Medical Protection Society (1929-77), to the livery of the Worshipful Society of Apothecaries (1952) and to the Fellowship of the Royal College of Surgeons of England (1956).

A. J. E. Cave 